\title{
Mitografía y manipulación iconográfica de la muerte de Cleopatra en la pintura occidental ${ }^{2}$
}

\author{
Mythography and Iconographic Manipulation of the \\ Death of Cleopatra in the Western Painting
}

\begin{abstract}
RESUMEN
Cleopatra es una de las figuras históricas que más repercusión y fama posterior han tenido, y uno de los temas más recurrentes en toda la pintura occidental. El episodio de su suicidio cobró un gran protagonismo en la pintura entre los siglos XVI y XIX. Sin embargo, esa construcción iconográfica que se hizo de su muerte estaba basada en la visión fraudulenta que la campaña política de Octavio transmitió. Se divulgó la imagen de una reina devora hombres, capaz de cualquier cosa con tal de mantener el poder. La pintura a partir del s. XVI no solo mantuvo esta idea, sino que añadió algunos elementos iconográficos que han contribuido de manera notable a la creación del mito de Cleopatra, como el pintar el áspid del tamaño de una lombriz. En este artículo, partiremos de las campañas de desprestigio romanas para hacer un análisis de las falsedades sobre su muerte que la iconografía posterior legó a nuestros días, y que contribuyeron que la distorsión de la imagen de la reina.

Palabras clave: Cleopatra, iconografía clásica, mitografía, iconografía femenina, recepción del mundo antiguo.
\end{abstract}

\section{Abstract}

Cleopatra is one of the historical figures that have had more impact and subsequent fame, and one of the most recurring themes in all Western painting. The episode of her suicide gained great prominence in the painting between the 16th and the 19th centuries. However, that iconographic construction that was made of his death was based on the fraudulent vision that Octavio's political campaign conveyed. The image of a queen as a femme fatale, capable of anything in order to maintain power was disclosed. The painting from the 16th century not only maintained this idea, but also added some iconographic elements that have contributed significantly to the creation of the Cleopatra's myth. For example, painting the asp the size of a worm. In this research article, we will start from the Roman smear campaigns to make an analysis of the falsehoods about her death that later iconography bequeathed to our days, and that contributed to the distortion of the image of the queen.

Keywords: Cleopatra, iconography, mitography, female iconography, Classical reception studies.

\section{SUMARIO}

1.- Introducción. Cleopatra y la campaña romana de desprestigio. 2.- El suicidio de Cleopatra convertido en pintura erótica. 3.- La pintura de finales del siglo XVIII y XIX: Cleopatra no se desnudó para morir. 4.- El áspid: el tamaño sí importa. 5.-El áspid no le picó en el pezón. 6.- Conclusiones. -Referencias / Bibliografía.

1 Universidad Camilo José Cela/ Universidad Complutense de Madrid. ana.valtierra@ymail.com

2 AGLAYA. Estrategias de Innovación en Mitocrítica Cultural, Proyecto de Investigación de la Comunidad de Madrid y el Fondo Social Europeo (ref. H2019/HUM-5714). 


\section{1.- Introducción. Cleopatra y la campaña romana de desprestigio}

Cuando Cleopatra conoció a Julio César en el 48 a. C., tan sólo era una joven de 20 años, frente a los 52 que tenía el experto e inteligente general romano. Pese a la marcada diferencia de edad, y que estamos hablando de uno de los líderes más poderosos de la antigüedad, la historiografía tradicional ha insistido en dibujar la figura de la reina como una devora-hombres maligna, que seducía al prójimo para manejarle a su antojo. Sin embargo, resulta difícil creer que un hombre de la edad, experiencia e inteligencia de Julio César, fuera tan manejable con tal de satisfacer un capricho sexual a manos de esta joven. Más aún si pensamos en que César fue famoso en la época por su activa vida sexual con hombres y mujeres. Tanto, que en Roma se decía de él que era el marido de todas las mujeres y la mujer de todos los maridos (Suetonio, La vida de los Doce Césares, I, 52, 3).

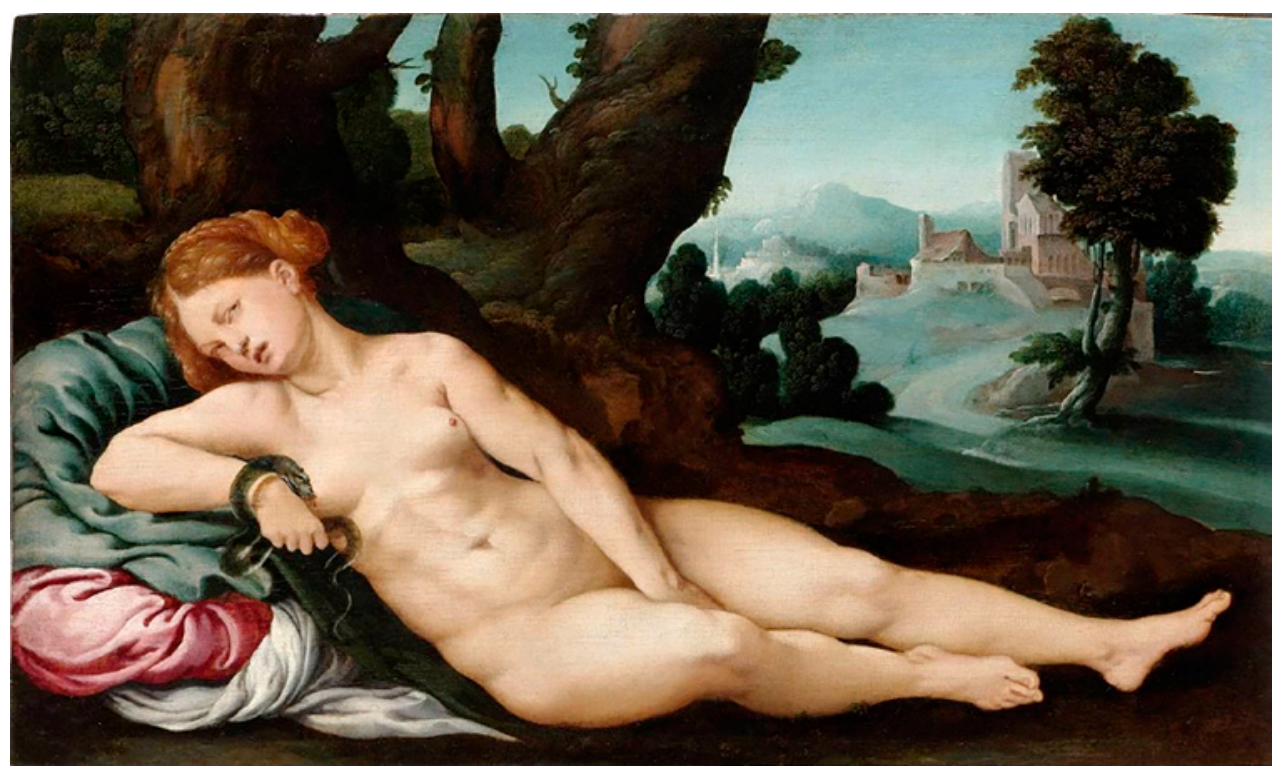

1. Jan van Scorel, 1523, óleo sobre lienzo. Rijskmuseum (Amsterdam).

Más llamativo todavía resulta pensar que a su muerte en el 30 a. C., Cleopatra era invocada por los romanos como regina meretrix. En tan sólo dieciocho años una sola mujer se granjeó el sobrenombre de male nostrum por parte del imperio más poderoso de la tierra. La consideraron un enemigo común, alguien a quien destruir a toda costa. La reina se convirtió en el blanco de una campaña política que como trasfondo pretendía desprestigiar la figura de Marco Antonio, y cuyo origen fueron las guerras producidas en el segundo triunvirato.

A la muerte de Julio César quedó establecido este segundo triunvirato, que como ya señaló Martin (1990:105) tuvo importantes repercusiones en la política de Cleopatra. Tanto Octavio como Marco Antonio, en su lucha por controlar el imperio romano, diseñaron agresivas campañas de propaganda política. Octavio 
se presentó como el garante de las buenas tradiciones romanas y, pese a que sería el primer emperador, como el defensor de la república que aborrecía la monarquía, que consideraba propia de bárbaros. En el pensamiento romano de la época estaba muy mal visto atacar a un general romano condecorado, se consideraba que iba en contra de los valores establecidos. De esta manera, ante la imposibilidad de Octavio para atacar a Marco Antonio sin manchar su propia reputación, lo que hizo fue utilizar su relación con Cleopatra. Según esta campaña de propaganda política, el general romano tan solo era un gran hombre, un grandioso militar que había tenido la mala suerte de caer en las garras de una pérfida mujer que lo estaba manipulando. Todo valía para conseguir gobernar en la casi totalidad el mundo conocido y el precio les pareció pequeño: la reputación de una mujer. Así, lo que se trasmitía en este mensaje era que no era el varón el que se había equivocado, el que había caído, sino que una mujer había anulado su voluntad, convirtiéndolo en una marioneta al servicio de sus deseos (Ruiz Garrido, 2006: 176).

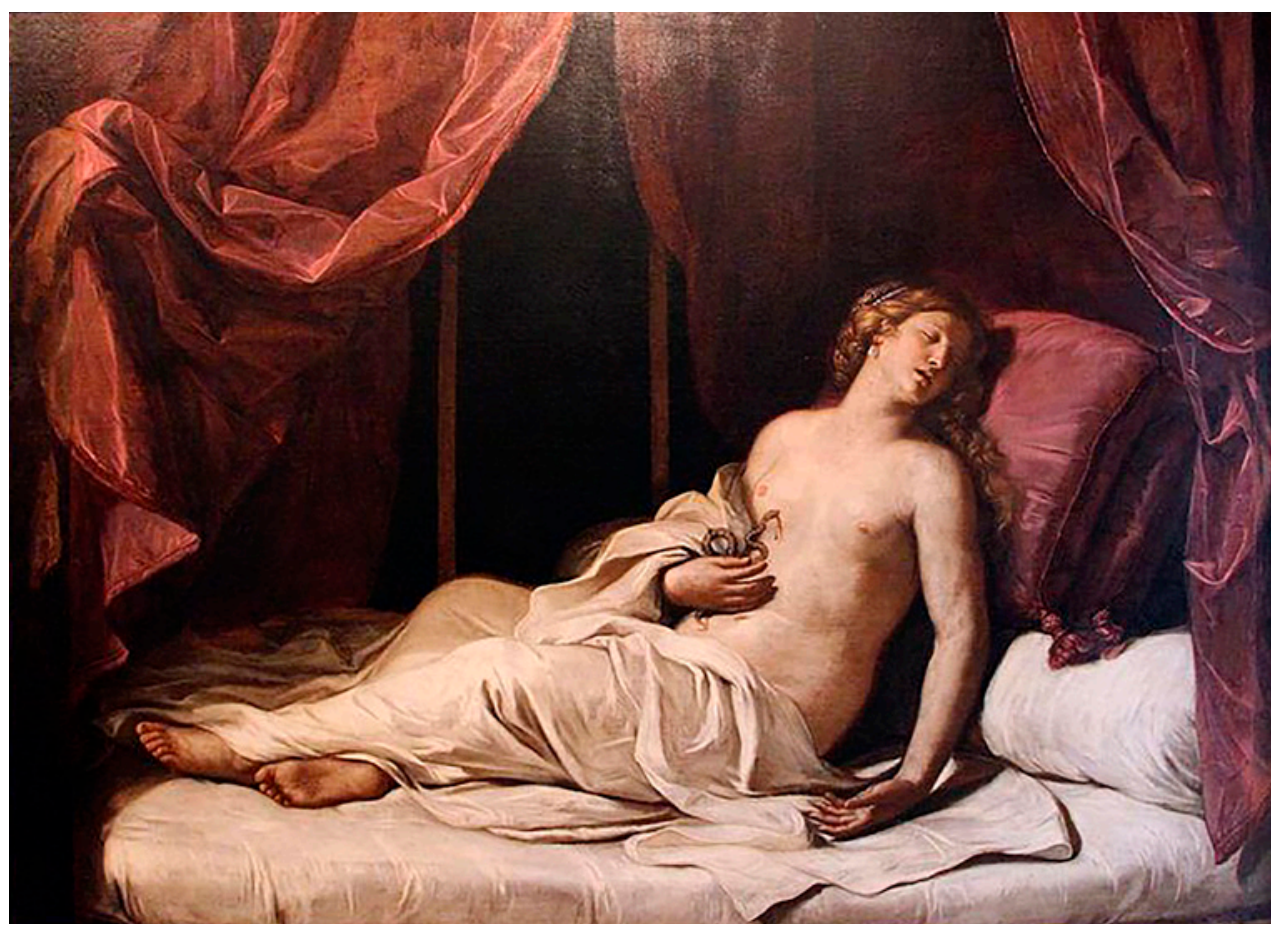

2. Guercino, 1648, óleo sobre lienzo. Musei di Strada Nuova - Palazzo Rosso, Genova

Cleopatra no era una mujer casta, lo que garantizaba un éxito fulminante en esta fórmula que se repitió hasta la saciedad en la pintura y la literatura. Ella decidía por sí misma y no en función de lo que le dictaba un hombre. Esta personalidad arrolladora de la reina fue clave para Octavio, gran estratega y mejor diseñador de su imagen para conseguir el poder. No dudó en servirse de la manipulación política llena de falacias sobre la figura de la reina. El triunviro sabía que era mejor 
ser recordado por luchar contra extranjeros que contra sus propios ciudadanos, que era a fin de cuentas lo que estaba haciendo contra Marco Antonio: sumir a su país en una guerra civil. En este sentido la figura de Cleopatra fue el puntal perfecto para esta campaña, puesto que encerraba todo lo opuesto al ideal de matrona romana.

Así, Cleopatra fue despojada de cualquier significado político, cuando los datos que nos llegan son precisamente de lo contrario: una mujer que se esforzó por afianzar su figura como reina (Arroyo de la Fuente, 2013: 69-106). Su muerte, único acto reconocido por los romanos como de calidad moral, fue un acto gobierno. Fue su última gran victoria, con la que quitó a Octavio el triunfo final (Valverde y Picazo, 2008: 515-530).

Esta campaña de desprestigio contra Cleopatra se fraguó de manera temprana, convirtiéndose en un acto consciente e intencionado de vilipendiar su biografía.

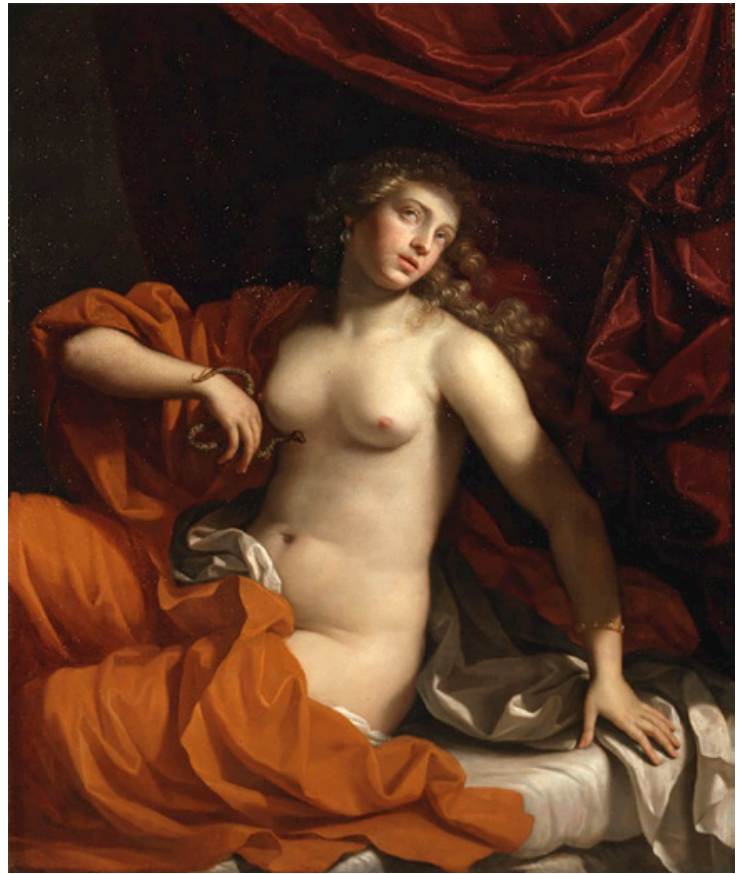

3. Benedetto Gennari, 1674-1675, óleo sobre lienzo, Centro de Arte Británico de Yale
Cicerón directamente afirmó reginam odi («odio a la reina», Cicerón, Cartas a Ático: XV, $15,15)$, una expresión exageradamente tajante que nos da una idea clara de la poca objetividad con que se trazó su semblanza por parte de los defensores de la tradición en su estilo más purista. El círculo del ya emperador Augusto impulsó estos insultos. Propercio (Elegías, 3, 11, 39) la llamó prostituta (meretrix regina), y seguramente el mismo año del fallecimiento de Cleopatra Horacio publicó su Oda Nunc est bibendum (Odas, I, XXVII), donde celebraba la muerte de Cleopatra diciendo que ahora era el momento de beber y celebrar. No menciona su nombre, pero se refiere a ella como reina embriagada de su fortu-

na, o incluso como fatale monstrum. A pesar de esto, el nombre de Marco Antonio no aparece, dando la impresión de querer blanquear la existencia de una guerra civil que culminaba con la muerte del general y la reina. El motivo de regocijo para Horacio parece expresar el hecho de terminar con una amenaza extranjera que poco o nada tenía que ver con la verdad: una disputa por el poder dentro del seno del territorio romano.

Los autores posteriores no se quedaron atrás. Lucano se refiere a ella como dedecus Aegypti («deshonra de Egipto», Lucano, Farsalia: X, 59) y Romana petit inbelli signa Canopo Caesare captiuo Pharios ductura triumphos («dispuesta a celebrar el triun- 
fo en Faros con un César como prisionero», Lucano, Farsalia: X, 64-65). Incluso se atreve a disculpar a Marco Antonio porque, quis tibi uaesani ueniam non donet amoris, Antoni, durum cum Caesaris hauserit ignis pectus? ("¿quién puede reprocharte el perdón por tu amor insensato, Antonio, cuando el mismo fuego consumió el duro pecho de César?», Lucano, Farsalia: X, 70-72). Lo mismo en Apiano, Flavio Josefo o Suetonio, o incluso Plutarco y Dión Casio, intentando realizar un análisis más real, no pudieron escapar de la contaminación de la biografía de la reina en función de sus amantes.

$\mathrm{Ni}$ siquiera los historiadores más actuales, cuyos estudios deberían perseguir la

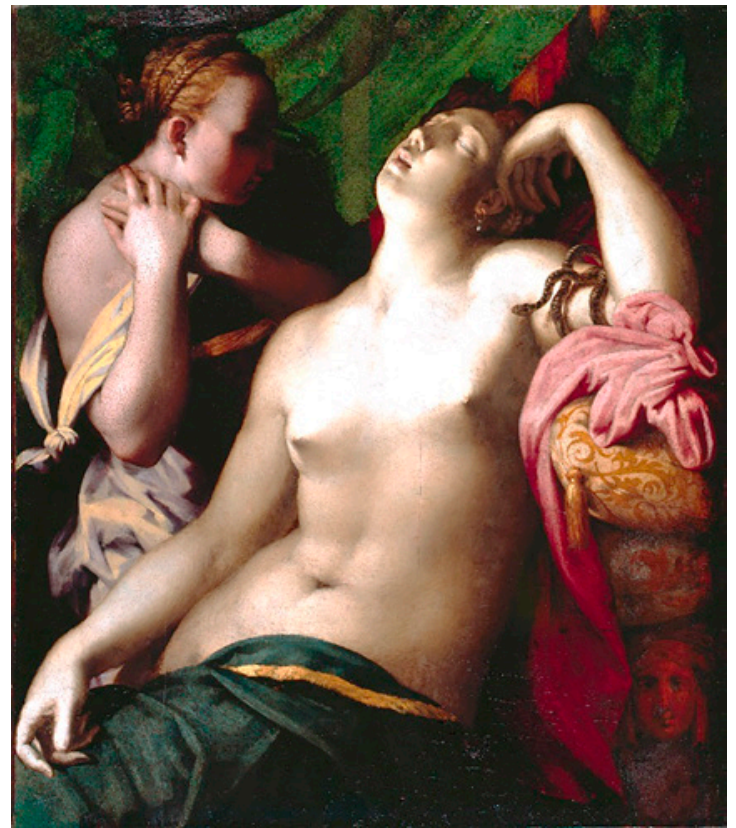

4. Rosso Fiorentino, ca 1525, óleo sobre lienzo. Herzog Anton Ulrich-Museum rigurosidad, han sabido escapar de esta visión prejuiciosa de la figura de Cleopatra trasmitida por los escritores romanos (Cid, 2000: 125). Así, es común entre colegas reiterar la idea repetida hasta la saciedad por la campaña romana de Cleopatra como devora-hombres, una suerte de femme fatale en cuyas redes cayeron los varones más fuertes. Así, la imagen creada a través de estas maniobras políticas de desprestigio traspasó el tiempo, e influyó de manera decisiva en la representación de uno de los pasajes más representados de su biografía: su muerte. Cleopatras seductoras, desnudas y con la serpiente picándole en el pezón. Un absurdo iconográfico que, a pesar de mantenerse durante siglos, poco o nada tiene que ver que con la realidad.

\section{2.- El suicidio de Cleopatra convertido en pintura erótica}

El episodio más representado de la vida de Cleopatra fue, sin lugar a duda, su suicidio por un áspid. Sin entrar en consideraciones sobre la veracidad o no de su muerte por reptil, durante los siglos XVI y XVII este tema alcanzó una popularidad desbordante en la pintura. Concretamente, la representación se ceñía al momento inmediatamente anterior a su defunción reducido a dos momentos clave: el gesto en sí mismo de hacerse picar por la serpiente o la agonía producida por el veneno, siendo escasos los ejemplos, como Artemisia Gentileschi de ca 1630 (colección privada de Londres), en los que se la pinta ya fallecida.

Según Plutarco (Antonio, 85,1-7), parece ser que un mensaje puso en conocimiento de la reina que en tres días sería conducida junto con sus hijos a Roma. Octavio 


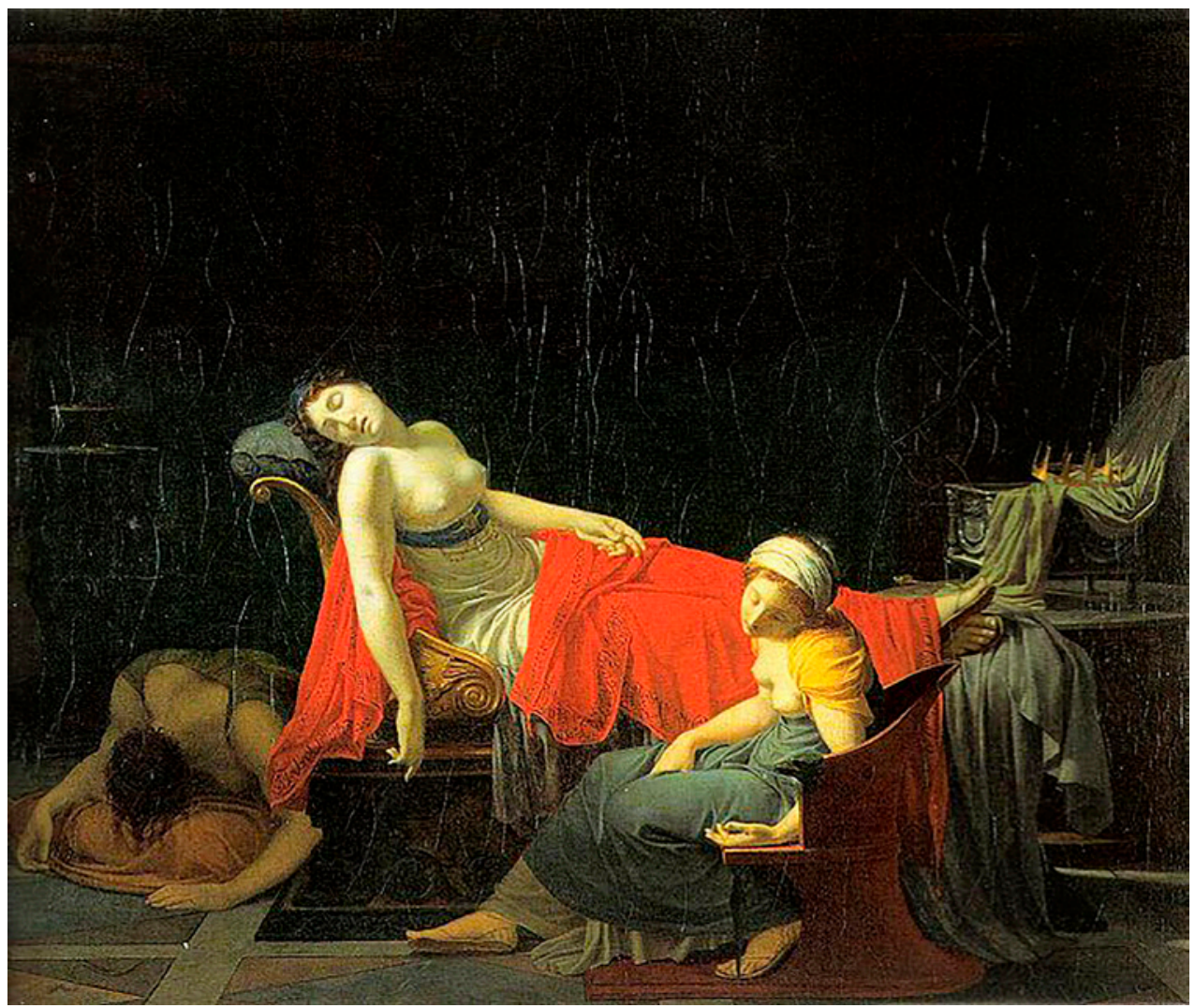

5. Jean-Baptiste Regnault, 1796, óleo sobre lienzo. Museo Palacio de Arte de Düsseldorf

pretendía llevársela y someterla a la humillación más grande: ser exhibida como trofeo de guerra en una procesión triunfal que se había organizado para celebrar su victoria en la guerra civil. La gran reina acabaría sus días como prisionera política o ejecutada en un espectáculo público. Así, lo que hizo fue que después de visitar la tumba de Marco Antonio, tomó un baño y una gran cena. Entregó un mensaje para que se lo diera a Octavio en el que pedía que como última voluntad que la enterraran junto a su amado, y se quedó con dos sirvientas, Charmion y Eiras. Octavio, al leer el mensaje, se dio cuenta de lo que iba a pasar. Mandó a toda prisa a los soldados, que empujaron a los ignorantes guardias que custodiaban las puertas de la habitación donde ya yacía muerta Cleopatra sobre un diván de oro. Eiras, ya había fallecido a sus pies, mientras que Charmion, a la cual le empezaban a hacer efecto el veneno, intentaba con gran esfuerzo colocar la corona.

Con menos detalles, pero en la misma línea recogieron el momento Suetonio (Augusto, 27,8) y Dión Casio (Historia romana, 8, 51, 14). Esta narración tan teatral y fantasiosa de las fuentes escritas relativa a la defunción de Cleopatra, fue recreada una y otra vez por la pintura. En parte, por la insistencia de las fuentes antiguas 
en la idea de que su muerte fue el aspecto más loable de su vida. De esta manera, evitaría la humillante exposición en el desfile triunfal de Roma (Horacio, Odas, I, XXVII). Fue un hecho histórico, una decisión premeditada que pretendía evitar a toda costa un destino quizá peor que el propio fallecimiento.

Sin embargo, la pintura de los siglos XVI y XVII insiste en escenificar su suicidio alejado sustancialmente de su connotación histórica y política. Tampoco trasciende al lienzo la idea de una reina que ha perdido una guerra, o el fin de una era en un imperio como el egipcio, que sería quizá la parte más notable de esta defunción. Al contrario, Cleopatra es reflejada una y otra vez como la amante que no soporta el haber perdido a su querido Marco Antonio, es una muerte por amor (Valverde y Picazo, 1990: 524-525). Como si la grandeza de la mujer no pudiera existir al margen de sus pasiones más viscerales.

Es más, a partir del siglo XV, y sobre todo en el XVI y XVII la representación de Cleopatra está fuertemente erotizada. Aparece normalmente desnuda parcial o totalmente y con el áspid. En multitud de ocasiones está representada sola y, en menor medida, en compañía de sus esclavas. Los ejemplos los tenemos a centenares. En 1523 Jan van Scorel en un óleo sobre tabla expuesto en el Rijksmuseum de Amsterdam (fig. 1), pintó a la reina tumbada, al aire libre, totalmente desnuda y con un áspid un tanto personificado con cara de malvado, enroscado en la mano derecha. Este «retrato» un tanto pornográfico de «Cleopatra» que sigue el modelo de las Venus, poco o nada deja a la imaginación, salvo la parte de la vagina en sí, tapada por la propia mano de Cleopatra. Guercino en 1648 en el óleo que se expone en el Musei di Strada Nuova (Génova) (fig. 2), nos presenta a una bella Cleopatra semidesnuda, con tan solo una tela que le deja los pechos y gran parte del pubis al descubierto. En la mano derecha, el supuesto áspid. Y unos años más tarde, en 1674-1675 Benedetto Gennari, en su pintura del Centro de Arte Británico de Yale (fig. 3) vuelve a insistir en ese modelo de Cleopatra de larga melena cubierta con una sábana que de manera un tanto «casual» se ha caído y deja entrever, además de sus pechos, su pubis. Es decir, de manera reiterada en los siglos XVI y XVII encontramos estas representaciones solitarias de Cleopatra identificable como tal tan solo por el áspid que las acompaña. Ni el decorado, ni los personajes, ni la vestimenta, ni la corona. Nada en absoluto que la identifique como reina de Egipto, tan solo elementos que hermanan con esa idea de femme fatale fraguada desde antiguo.

A veces Cleopatra no está sola, sino que aparece parte del cortejo que la acompañó en tan duro trance. La representación no solo no varía, sino que se aprovecha para multiplicar el erotismo al poner a las esclavas desnudas o con los pechos al aire. Así por ejemplo en la pintura de hacia 1525 de Rosso Fiorentino conservada en el Herzog Anton Ulrich-Museum (fig. 4). Cleopatra, extrañamente rubia (Dauphiné, 1995: 95-101), está sentada y con el torso desnudo, tiene una serpiente enroscada en su brazo izquierdo.

Cabe afirmar de manera taxativa que la idea en la que insiste la pintura de que Cleopatra murió desnuda está en contradicción directa con lo que narran las fuentes antiguas. Unas fuentes, recordemos, que ya la reflejaban como prostituta y 


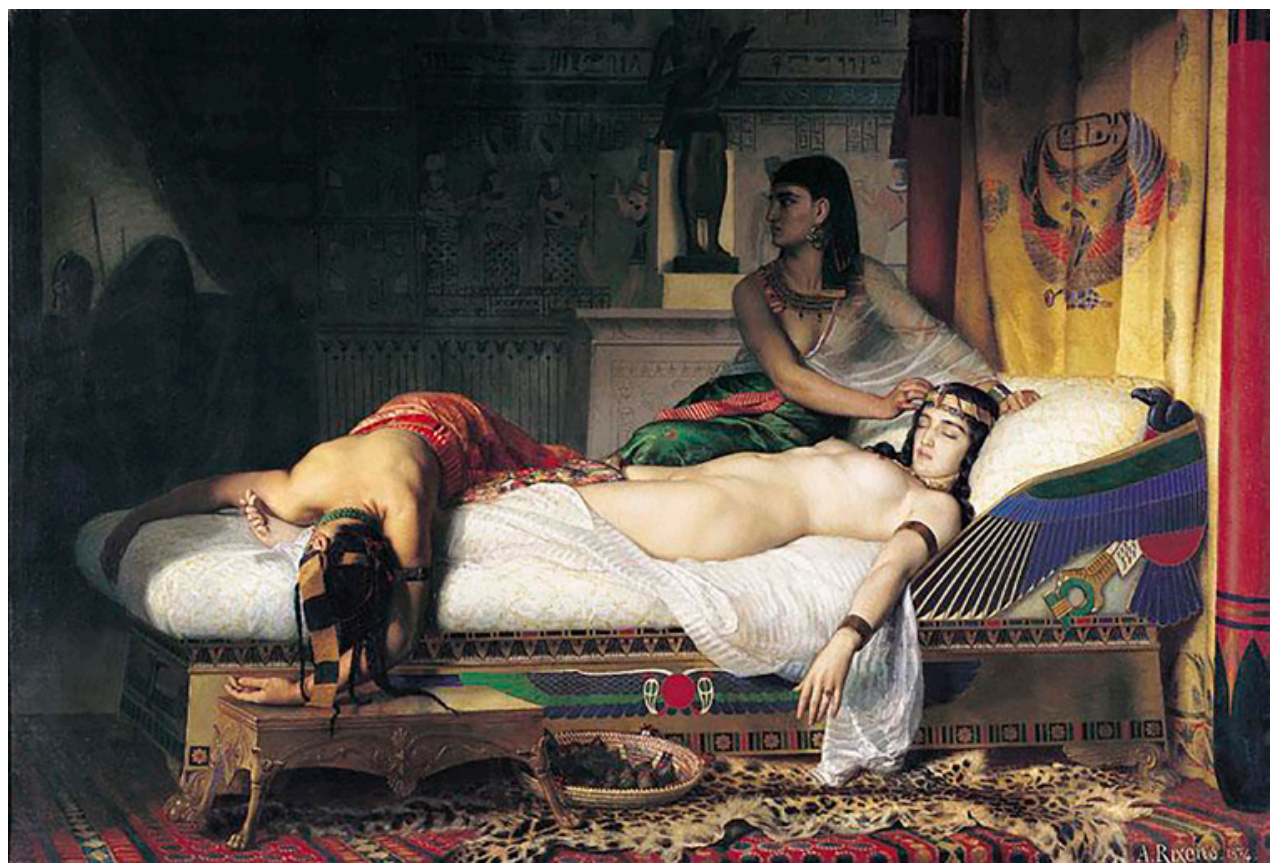

6. Jean-Andre Rixens, 1874, óleo sobre lienzo. Museo de los Agustinos de Toulouse

mala mujer, pero que ni aún por esas se atrevieron a afirmar semejante desmesura. A fin de cuentas, no tiene ningún sentido que una reina en el momento de suicidarse decida quitarse la ropa para morir. ¿Con qué fin una poderosa gobernante haría eso? ¿querría que encontraran su cuerpo desprovisto de ropa y ser recordada por su sensualidad? Evidentemente no, se trata de una invención plástica que sirvió para cubrir la demanda en el mercado artístico de encargos de varones que disfrutaban con el placer solitario y la excitación que les proporcionaban la contemplación de estas pinturas. Cleopatra era un símbolo de las costumbres sexuales laxas, y su representación proliferó en estos óleos que los caballeros guardaban en salas privadas para regocijo de su propia fogosidad. Es más, la picadura y el veneno haciendo su efecto fueron elementos usados como excusa para poder representarla en el compendio más variado de posturas, o en medio de una convulsión corporal que se asemejaba a un orgasmo, y que multiplicaría el placer de estos voyeurs en su contemplación.

\section{3.- La pintura de finales del siglo XVIII y XIX: Cleopatra no se desnudó para morir}

A partir de finales del siglo XVIII, el interés por ampliar la escena del fallecimiento de Cleopatra se fue intensificando. Se abrió el marco, y las Cleopatras solitarias o en escenarios reducidos, fueron dejando paso a la representación cada vez más completa de la escena. Así, Jean-Baptiste Regnault entre 1796 y 1797 (fig. 5) pintó a la reina semiacostada en un diván ya muerta, con sus dos esclavas 


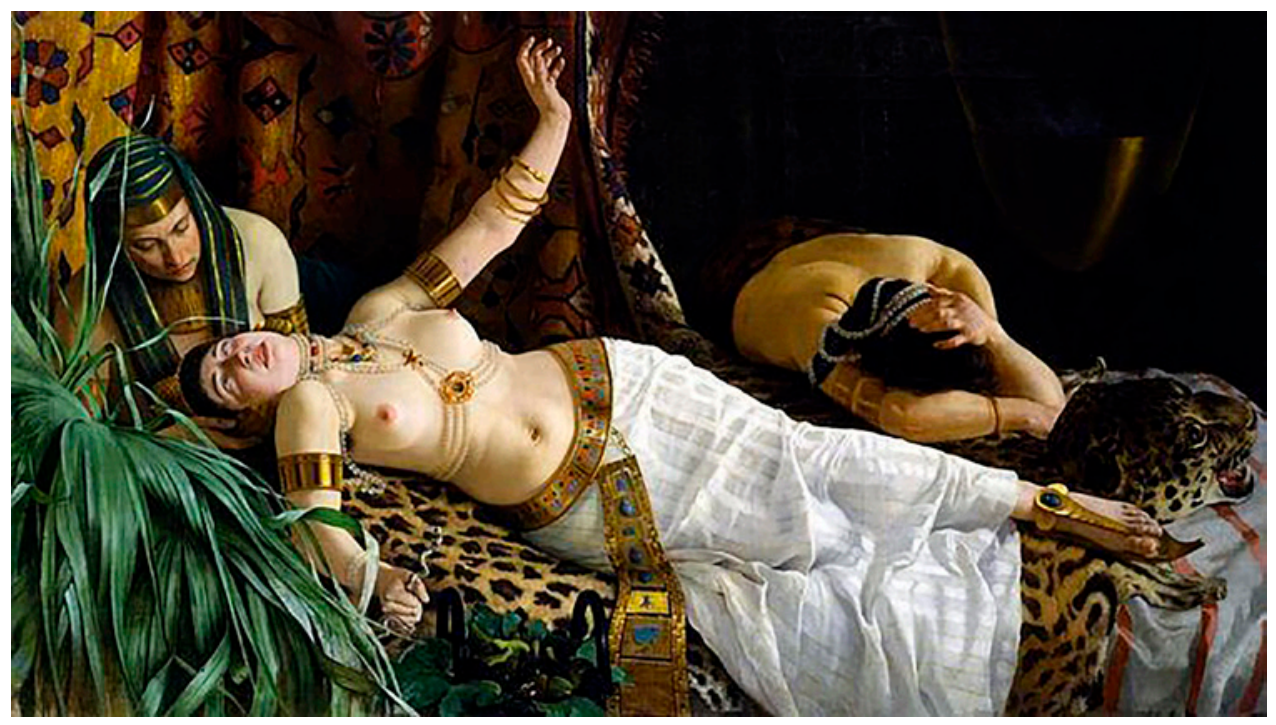

7. Achille Glisenti, 1878, óleo sobre lienzo. Museo della Città, Santa Giulia, Brescia

yacentes, una en el suelo y otra sobre una silla. Es una belleza serena, casi estoica alejada de pasiones viscerales, lo cual no le exime de dejar los pechos de la reina y de una de sus esclavas al descubierto. Es cierto como señala Garrard (1989: 214) que los suicidios masculinos en el arte son acciones públicas o políticas en ara de ideales elevados, mientras que los suicidios femeninos son en general actos privados de desesperación. Esa es exactamente la tónica de las pinturas de estos años, ejemplificada en estas líneas por Regnault: un acto tan íntimo que la reina lo hace semidesnuda en su habitación. Así, frente a las inmolaciones de Séneca, Demóstenes o Catón de Útica, que se consideran una afirmación pública de su vida (Griffin, 1986: 64-67), la muerte en Cleopatra se convirtió en su único acto ejemplarizante. Eso sí, iconográficamente hablando siguió teñido por esa vida de depravación que injustamente se la atribuyó. Tal y como había vivido, tenía que morir.

La pintura del siglo XIX, impregnada con un afán supuestamente historicista, comenzó a buscar la reconstrucción pictórica del suceso. Las pinturas sobre el suicidio de Cleopatra sufrieron en este sentido una curiosa metamorfosis por la cual, mientras parecía que con las fuentes antiguas en la mano se reconstruían los hechos a golpe de pincel, seguía prevaleciendo la idea de Cleopatra desnuda. Uno de los mejores ejemplos de esta tónica fue Jean-André Rixens en La muerte de Cleopatra, un óleo de 1874 que actualmente se exhibe en el Museo de los Agustinos de Toulouse (fig. 6). La reina y Eiras yacen muertas, mientras que Charmion, que la está colocando la corona, se gira ante el estruendo que arman los romanos al entrar en la habitación por la puerta del fondo a la izquierda. Sin embargo, un detalle no concuerda con lo que parece que fue la realidad y sí con la imagen que nos ha llegado de la reina: está desnuda. Cleopatra se quitó la vida en el mausoleo de Alejandría y según relatan las fuentes se hizo vestir con su atuendo de reina (Dión 
Casio, Historia de Roma 51,14 y Plutarco, Antonio, 85, 6). Es decir, murió haciendo una afirmación de su estatus de gobernante de Egipto algo muy lejano a la imagen erótica que este pintor nos transmitió. De esta manera, si verbalizamos el relato de Rixens, podemos afirmar que sigue literalmente el relato de Plutarco (Antonio, 85) salvo por el hecho de representar a Cleopatra completamente desnuda:

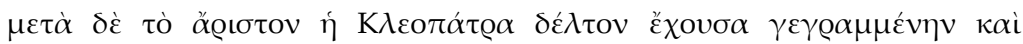

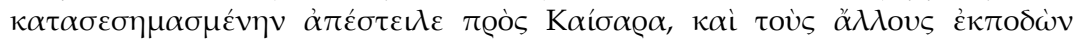

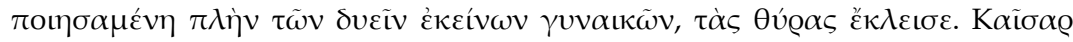

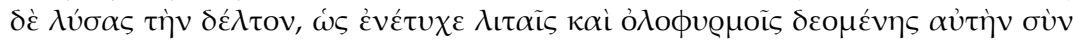

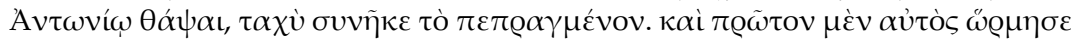

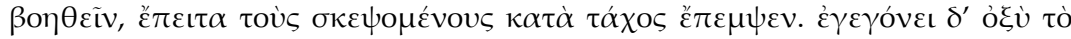

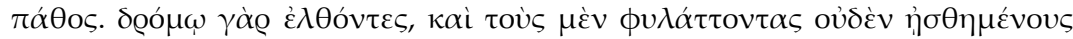

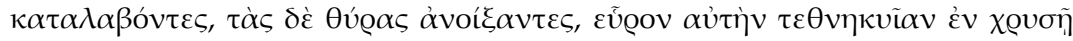

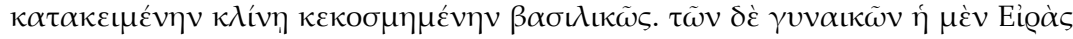

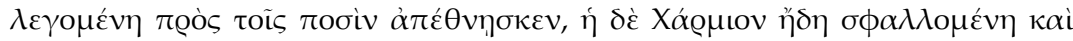

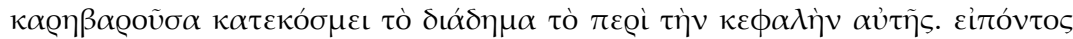

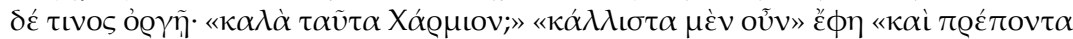

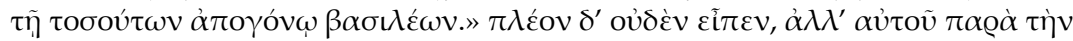

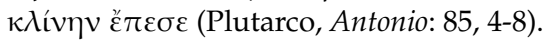

«César abrió la carta, en la que pedía con lamentos y súplicas que se le permitiera ser enterrada junto con Antonio y, tras leerla, comprendió rápidamente lo que había hecho. Su primer impulse fue acudir a prestar ayuda, pero después envió a unos cuantos para que acudieran a toda prisa. Debió de ser rápido el fin de Cleopatra, pues los enviados de César, al entrar a la carrera, apartaron a los guardas que no se habían enterado de nada y abrieron las puertas, pero la encontraron ya muerta y tumbada en un triclinio dorado, adornada como una reina. De las mujeres, la llamada ha, yacía sin vida a sus pies, y Camión, ya desfallecida y con la cabeza vacilante, adornaba la diadema que ceñía la cabeza de su señora. Al decir uno lleno de furia: '¿Te perece esto bonito?'; ella repuso: '¡Pues claro que me parece bien y propio de quien es la última descendiente de una dinastía de prestigiosos reyes!'. Pero no pudo decir más pues cayó allí mismo, al lado del lecho» (Plutarco, Antonio: 85, 4-8, trad. Juan Pablo Sanchez y Marta González).

Efectivamente, Rixens escenificó de manera casi literal el texto de Plutarco, pintando el momento exacto en que las tropas de Augusto entran a toda prisa en la estancia de Cleopatra para evitar su suicidio. Incluso detalla a Eira ya muerta, y a Charmion poniéndole la corona mientras gira su cabeza para escuchar las palabras del soldado. Pero obvia que el sacerdote especificó que estaba regiamente adornada. Ella quiso morir como reina, y por eso Charmion le pone la corona una vez muerta, porque es descendiente de muchos reyes.

Para los conocedores del escrito de Plutarco, la composición se antoja extraña, como una nota discordante en la sucesión de hechos relatada. No tiene sentido alguno que la reina estuviera desnuda para suicidarse. O peor aún, que la reina se desnudara para matarse para que la encontraran privada de su dignidad regia. Pero Rixens en el momento de componer esta obra está tan sumamente contaminado 


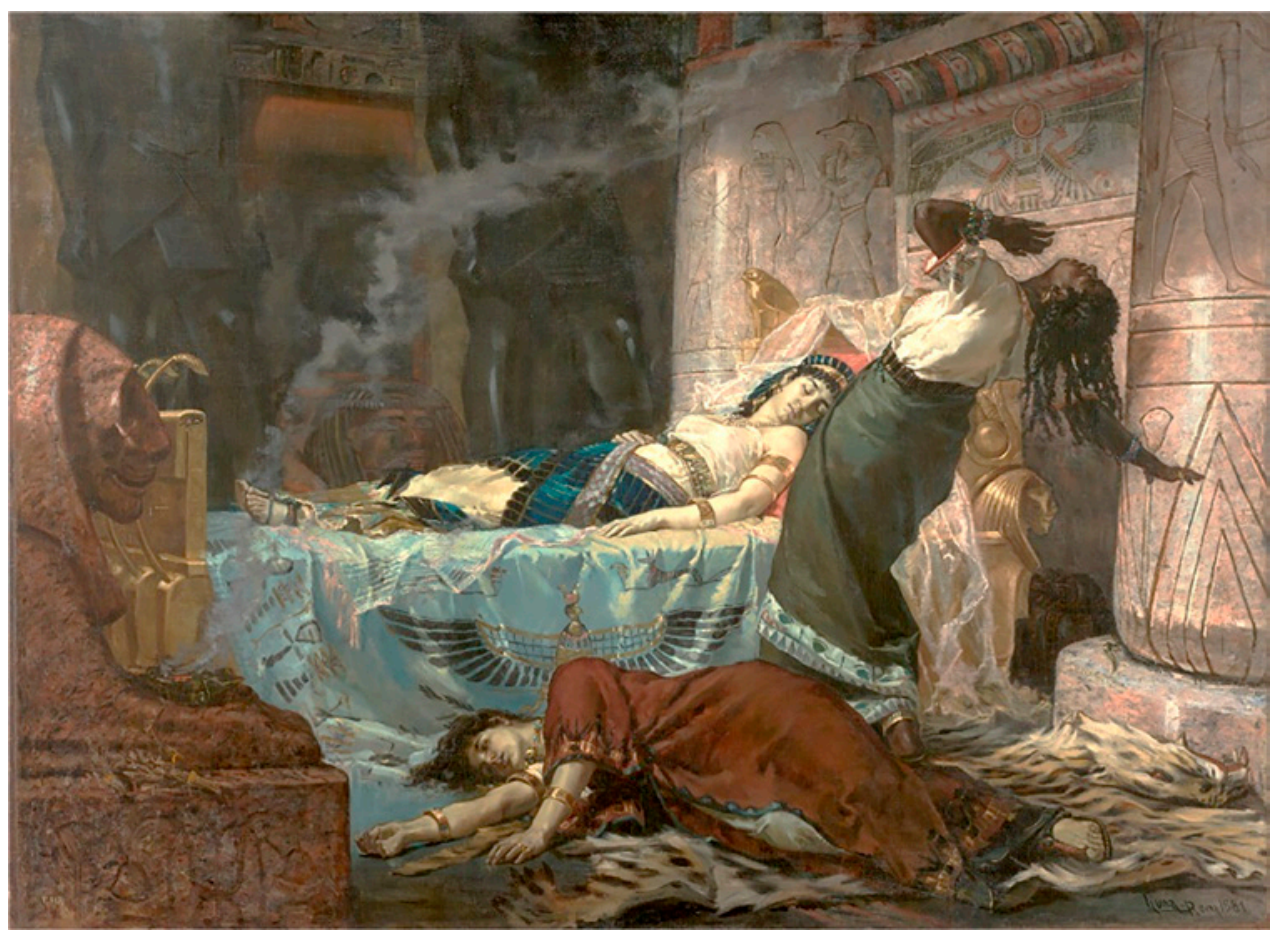

8. Juan Luna y Novicio, 1881, óleo sobre lienzo. Museo Nacional del Prado

por las representaciones plásticas realizadas a lo largo de los siglos anteriores, que no es capaz de concebir de otra manera a Cleopatra.

La pintura de Achile Glisenti realizada en 1878 (fig. 7) sigue el mismo planteamiento iconográfico que Rixens, pero la impresión visual que produce es bastante diferente. La reina en este caso está agonizando por el veneno, con los ojos en blanco, y su cuerpo se retuerce asemejándose a un orgasmo. Si nos fijamos en sus pechos, están modelados con mucho mimo, y coronados por sendos pezones rosados perfectamente marcados. Las joyas que lleva, que los rodean, sirven para enmarcarlos y destacar su belleza. El pintor se ha recreado en cada detalle del cuerpo de la reina, poniendo especial cuidado en resaltarlo en su máximo esplendor. No hay inquietud por el hecho histórico, ni por la dimensión política que trajo consigo, tan solo por retratar a Cleopatra como un culmen de la sensualidad centrado en la belleza de sus pechos.

En esta línea de pinturas, Juan Luna y Novicio realizó en 1881 una versión maravillosa guardada en el Museo Nacional del Prado (fig. 8). La reina ya está muerta en un lecho adornado con ricas sábanas y cabecero de oro. La arquitectura de detrás está decorada con relieves entre los que podemos distinguir la figura de Anubis, como una preconización de lo que va a suceder. Una de las esclavas yace muerta en el suelo, mientras la otra se retuerce a punto de caer. El humo inunda la estancia, dotando a la habitación de un ambiente misterioso. En este caso Cleopatra 


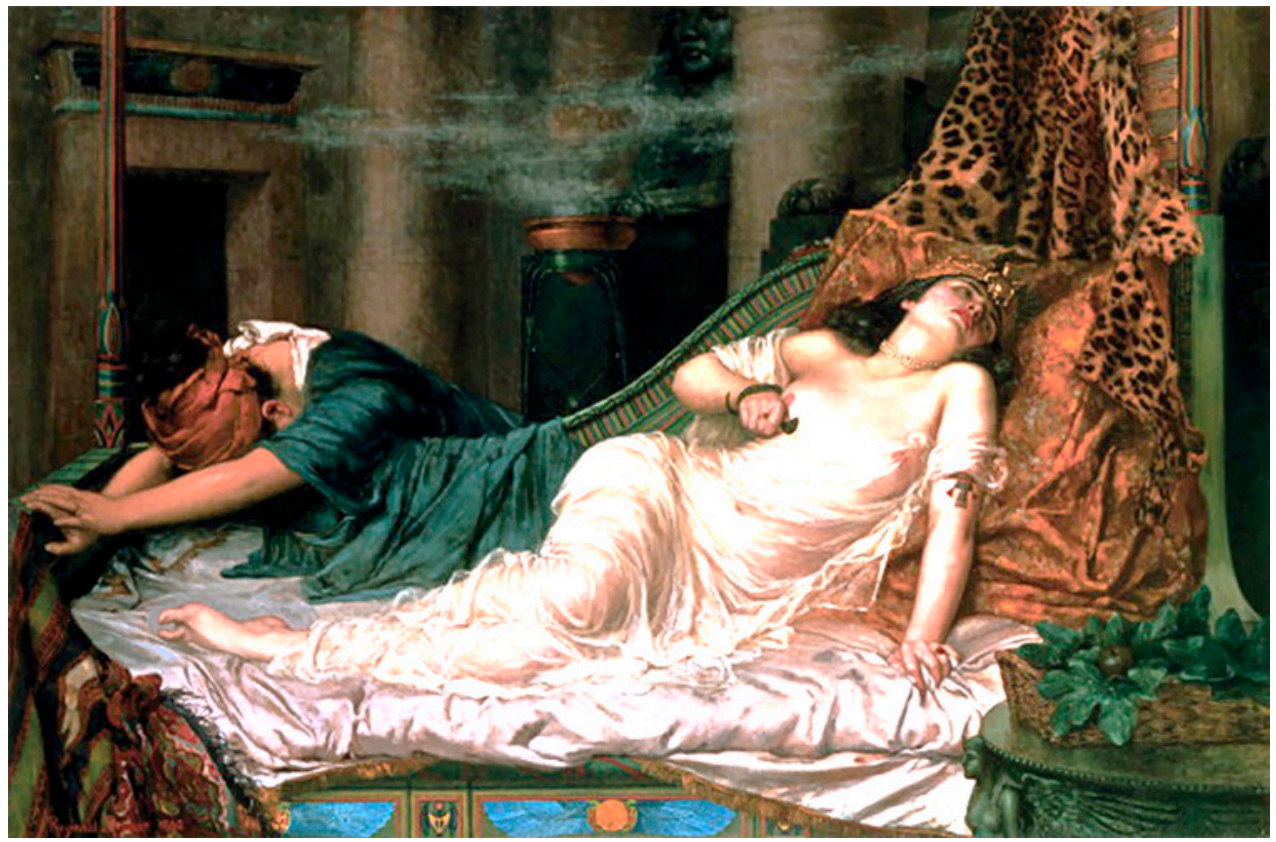

9. Arthur Reginald Smith, 1892, óleo sobre lienzo. Roy Miles Gallery, London

está vestida, pero de cintura para arriba la tela es transparente, dejando ver sus pechos. Una vez más el pintor no puede escapar de este concepto de Cleopatra erotizado.

La misma idea se refleja en la obra de Arthur Reginald Smith realizada en 1892 y actualmente en la Roy Miles Gallery de Londres (fig. 9). Cleopatra en un lecho cubierto por pieles de leopardo que acentúa la idea de exotismo, se retuerce por el veneno del «áspid» que todavía sostiene en su mano derecha. La tela transparente que cubre su cuerpo deja los pechos al descubierto, manteniendo solamente como símbolo de poder regio la corona. Detrás, una de sus esclavas ha caído. La escena tiene mucho movimiento, al retorcerse la reina presa del efecto del veneno. Como en el caso anterior, el humo de detrás dota a la escena de un halo de misterio.

Kenneth Clark (2006) establecía con respecto a las obras de arte, un curioso sistema para diferenciar el arte de la pornografía. Decía que cuando una imagen se convierte en un incentivo para la acción, se expulsa del ámbito del arte y entra en el de la pornografía. Se escapa a estar líneas la reflexión sobre la diferenciación del arte como sublimación, o la imagen pornográfica en su sentido más puro, para lo que remito a otros autores (Nead, 1998) pero sí que, ciñéndonos a esta definición marcada por Clark, cabría preguntarse cuántas de estas pinturas están pensadas para ser un incentivo para la acción. Es evidente que no hay intención de reconstrucción histórica, ni rigurosidad, ni representan las buenas formas que debía tener una mujer de la época. Están aisladas en la mayoría de los casos del resto de la escena, y pensadas para disfrute privado del quien contempla. 


\section{4.- El áspid: el tamaño sí im- porta}

Plutarco (Antonio, 85) narró cómo Cleopatra ya había experimentado con distintos venenos en el invierno del 31 al 30 a. C. Su intención era probar el dolor que causaban en presos, dándose cuenta de que sólo la picadura de áspid provocaba un deceso sin convulsiones ni sollozos, como una especie de sopor dulce. Esa idea de reina cruel, impasible, que observa sin inmutarse como los presos mueren a expensas de sus terribles ensayos para su futura muerte, fue pintada por Alexandre Cabanel en Cleopatra probando venenos con los prisioneros condenados (1887) del Museo Real de Be-

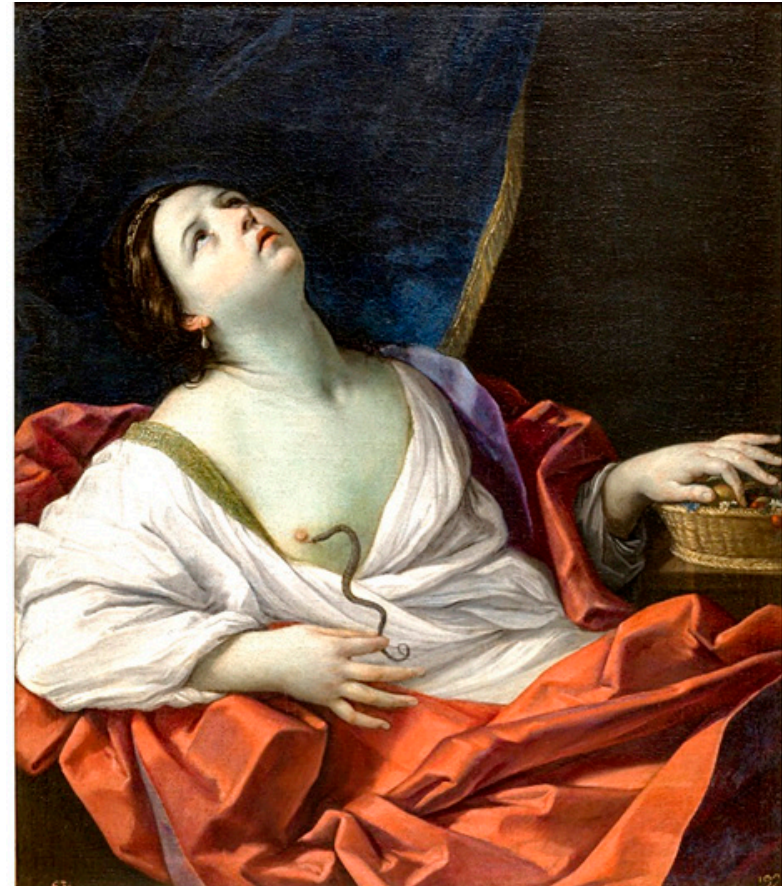

10. Guido Reni, 1640, óleo sobre lienzo. Museo Nacional del Pradosobre lienzo. Roy Miles Gallery, London

llas Artes de Amberes. Es una continuación de esa imagen de reina frívola a la que solo le importa mantener su poder a toda costa.

A pesar de esos relatos, es difícil asegurar que fuera un áspid introducido en una cesta de higos o tinaja lo que produjera el fallecimiento de Cleopatra. Se excede a estas líneas el desarrollo del estado de la investigación en este punto, pero es importante señalar que la idea de la falsedad de la muerte de Cleopatra por una picadura de áspid no es en absoluto novedosa. El mismo Plutarco (Antonio, 86) ya ponía en duda un suicidio tan teatral, aunque se terminó dando por buena esta causa por dos marcas en el brazo que se le encontraron.

A pesar de que hoy se contemple la posibilidad de que Octavio interviniera en su asesinato, parece que oficialmente intentó mantenerla con vida. Puede que incluso solicitara la ayuda de unos psylli, famosos por su habilidad en curar chupando el veneno, pero era demasiado tarde (Fletcher, 2009). Sus antiguos biógrafos, insisten en la bondad del emperador al querer salvarle la vida, pero parece más que fue por el interés de poder exhibirla en ese famoso triunfo. De hecho, en el mismo, que finalmente se celebró, se sustituyó a la Cleopatra de carne y hueso por una efigie de cera con un áspid en el brazo. Ese tipo de representación, de Cleopatra muriendo o agonizando con la serpiente enrollada en el brazo, fue muy popular.

Lo que es innegable, es que la serpiente se ha convertido en el elemento iconográfico más determinante a la hora de representar a Cleopatra. A veces, en las pinturas con un anhelo algo más reconstructivista, como era el caso de la pintura 


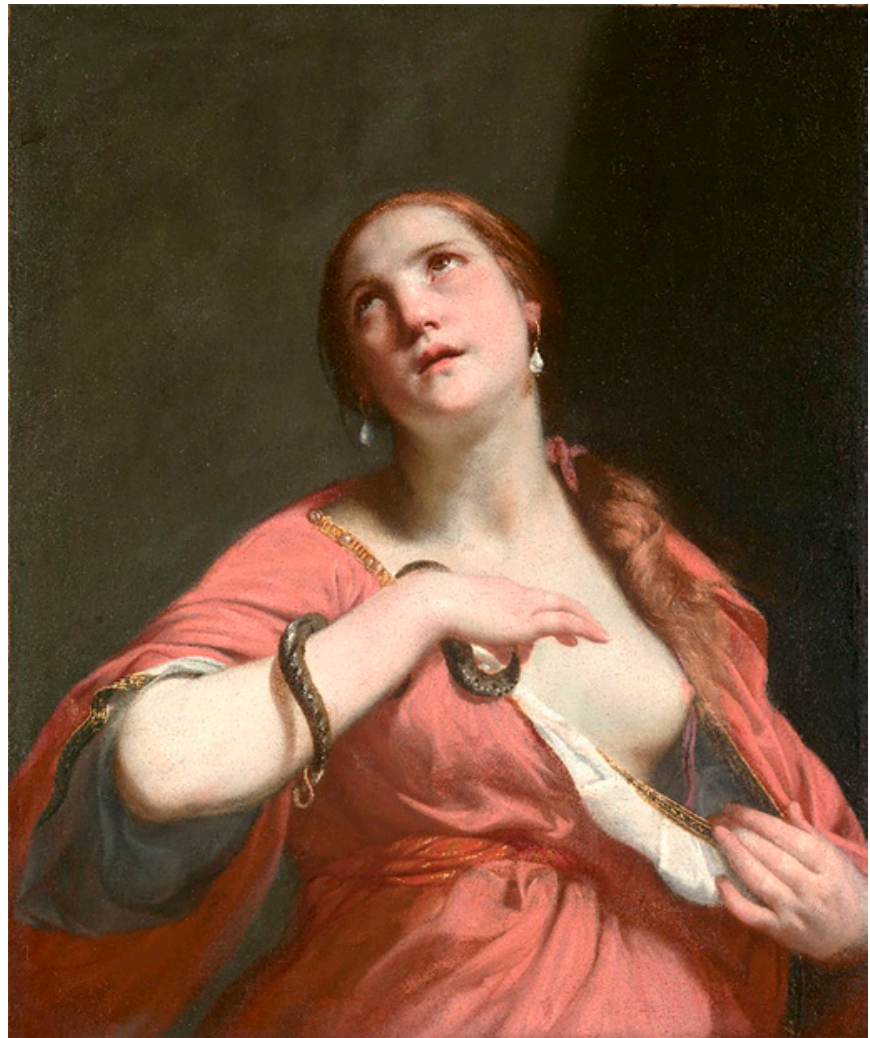

11. Guido Cagnacci, 1645, óleo sobre lienzo. Metropolitan Museum de Nueva York de Rixens, incluso aparece el cesto de higos al lado de la cama. Sin embargo, en muchos otros casos el abandono de elementos que la acompañen es tal, que solo podemos identificar a Cleopatra por el áspid que la acompaña, testigo del proceso por el que evitó el dolor y el deshonor. Es decir, la representación de la muerte de la reina está reducida a una mujer desnuda o, al menos, con los pechos al descubierto, que lleva en su mano una serpiente.

La cobra egipcia o áspid (Naja haje) puede medir hasta 2,5 metros de largo, es decir es un ejemplar grande $y$ hermoso (Trape, Chirio, Broadley, y Wüster, 2009). El tamaño mínimo que podemos calcular es de entre 30 y 40 centímetros de largo, que es el que tienen al nacer, pero también esto hace disminuir la cantidad de veneno que tienen, así como su capacitad para matar a alguien, que también disminuye. Es decir, que un áspid para poder matar al nacer tendría que infringir una picadura especialmente mortal, por ejemplo intravenosa en un gran vaso, a una persona de pequeño tamaño o enferma ${ }^{3}$, lo cual no cuadra con el perfil de Cleopatra y lo que nos han trasmitido las fuentes.

Sin embargo, las artes plásticas insisten en representar el suicidio de Cleopatra con serpientes cuyo tamaño se asemeja más a pequeñas culebrillas de río. Algunas, no sobrepasan los $10 \mathrm{~cm}$, y tienen el grosor de un gusano de seda. Así se pone de manifiesto en un óleo custodiado en el Museo Nacional del Prado. Se trata de la Cleopatra de Guido Reni pintada hacia 1640 (fig. 10), donde la reina semirecostada alza la mirada al cielo. Su mano izquierda se posa encima del cesto de higos, que

3 Estos datos están han sido aportados por Miguel Gallego Agúndez, veterinario y cofundador de la Clínica Veterinaria Madrid Exóticos. Mi agradecimiento a la resolución de dudas y los datos aportados sobre las características de la especie Naja haje. 
ha servido para camuflar la serpiente. Mientras que con su mano derecha sostiene la sierpe que dirige a su pezón desnudo. Es una pequeña culebrilla que nada tiene que ver con la majestuosidad del áspid.

Este hecho de disminuir notablemente el tamaño del arma homicida va unido a la idea de que lo femenino se asocia a objetos pequeños. Salvo en el caso de querer enfatizar la idea de «mujer fuerte», va a ser habitual poner las armas de la mujer de tamaño reducido, algo especialmente notable en multitud de imágenes femeninas, como la de Lucrecia, donde el cuchillo con el que se mata, el culter que menciona Tito Livio (Historia de Roma, I, 57-59) se convierte muchas veces en casi una aguja de tejer, fina y larga, o un pequeño

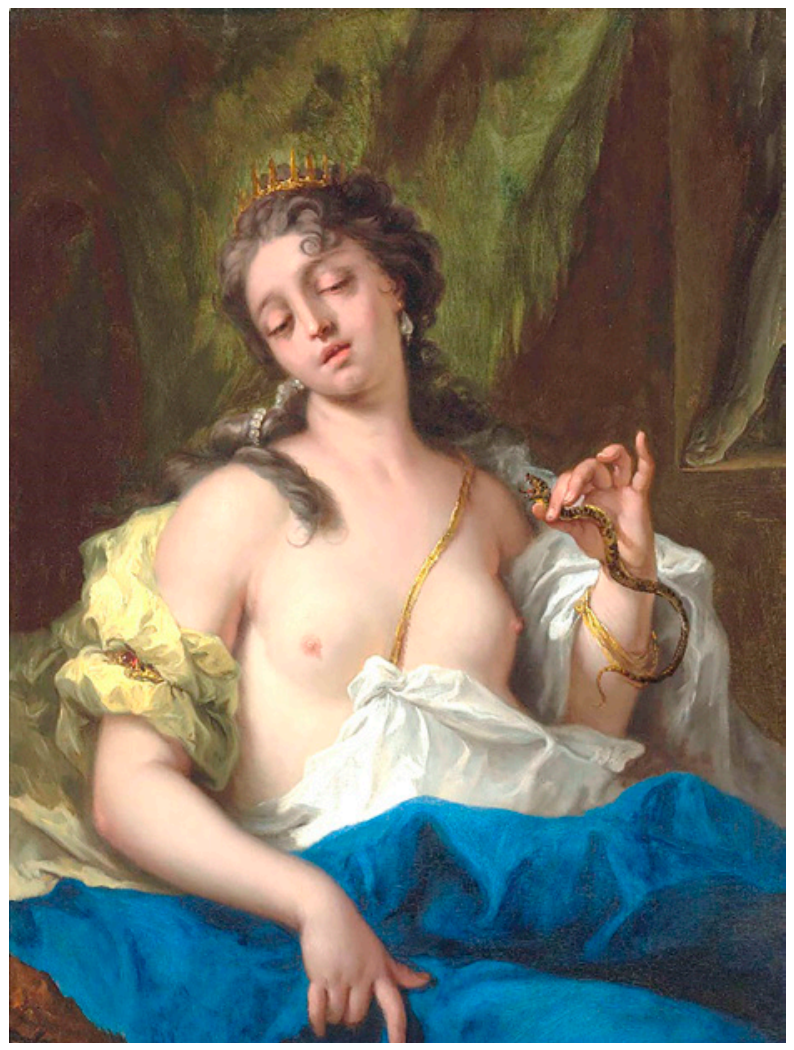

12. Sebastiano Ricci. óleo sobre lienzo puñalito que parece una navaja plegable más propia para ir de camping que para intentar quitarse la vida (Valtierra, 2014-2015, pp. 241-261).

La serpiente es a veces tan pequeña que Cleopatra puede cogerla con dos dedos, con delicadeza. Como si un áspid pudiera ser domado y sujetado sin apenas hacer fuerza. Es el caso de La muerte de Cleopatra de Guido Cagnacci (1645-1655) que se expone en el Metropolitan Museum de Nueva York (fig. 11). Es un gesto sexual, remilgado, que no pertenece en absoluto a el carácter de una poderosa mujer como fue Cleopatra. El mismo concepto lo encontramos en la pintura de Sebastiano Ricci (fig. 12): Cleopatra con los pechos al aire y la corona, sujetando en su mano izquierda un áspid que más parece una lombriz por su tamaño. La misma idea una y otra vez repetida en la pintura del reptil pequeño, delgado y fino.

Es evidente que la idea de representar el áspid de tamaño tan reducido fue una elección consciente de los artistas, que cuando querían pintar un reptil en otros contextos, como por ejemplo la tentación de Eva, sabían y podían plasmarlo de complexión grande. El motivo va ligado, como hemos mencionado ya, a la asociación de la figura femenina con los objetos pequeños, llevada a sus extremos más exagerados. Esta apreciación sobre la marcada disminución de tamaño del arma homicida ya fue puesta de manifiesto en siglos anteriores. Así, Thomas Browne en su 


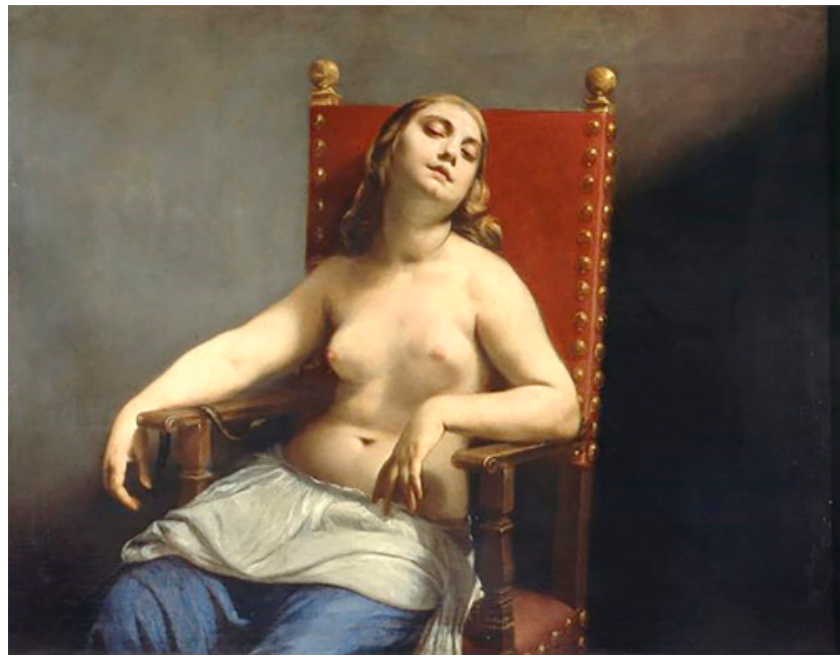

13. Guido Cagnacci, 1660, óleo sobre lienzo. Pinacote de Brera obra Pseudodoxia Epidemica publicada en 1646-1672 y dedicada a los errores populares en materias naturales e históricas, indicaba que las representaciones artísticas de pequeñas serpientes que mordían a la reina, no se correspondían en absoluto con el tamaño real del áspid terrestre. Es decir, se trataría de un error vulgar o creencia falsa que fue repetida plásticamente con el devenir de los siglos.

Es cierto que como hemos mencionado ya, el hecho de que fuera mordida por un áspid es cuanto menos dudoso. Por señalar algunos autores que han notado estas evidencias antes que yo, Roller (2010: 148) ya ponía de manifiesto que introducir a escondidas un áspid egipcio a escondidas, y encima hacer que se comportara como uno quisiera, no era tarea fácil. Y que por supuesto, un áspid no cabe en un cesto de higos (Retief y Cilliers, 2006: 85-87). Así, para intentar conjugar de manera algo lógica estas versiones, Wes (2000: 222-224) planteó la hipótesis de que esta teoría de la mordedura podría haberse originado como resultado del desfile triunfal de Octavio donde se mostró una imagen de Cleopatra vistiendo las túnicas de Isis y con el brazalete tradicional de la diosa (una serpiente enroscada) en su antebrazo. De esta manera, los espectadores romanos, que no conocían el simbolismo de esta imagen, habrían malinterpretado la secuencia. De hecho, Virgilio, Horacio y Propercio es probable que estuvieran en el desfile. En este sentido, sí que resulta llamativo que en algunas pinturas sobre su muerte aparezca representada con esta pequeña serpiente enroscada en el brazo que sigue el hilo de su imagen procesional.

En definitiva, representar una pequeña serpiente, en vez del majestuoso áspid, seguramente cuadraba mucho mejor en la mentalidad de los artistas posteriores. Una figura femenina capaz de sostener un áspid no encajaba bien en la construcción del erotismo pictórico, sino que usar algo pequeño para darse muerte producía el efecto de poder ser dominada por aquel que contemplaba la imagen.

\section{5.- El áspid no le picó en el pezón}

La historia del arte no solo ha insistido en la idea de los pechos desnudos, si no también en que la picadura se produjo en la propia mama o incluso en el pezón. Es decir, que según la interpretación plástica e historiográfica posterior Cleopatra 
para suicidarse, de todas las partes en las que se podía haber hecho picar por el áspid, eligió esa. Algo evidentemente inventado, a la par que poco práctico. Un ejemplo notable es la pintura de Guido Reni, quien le dedicó hasta cinco obras similares al tema. En la versión que se custodia en el Museo Nacional del Prado (ca. 1630), la reina mira hacia arriba, y ha dejado un pecho al descubierto, hacia cuyo pezón se dirige una diminuta serpiente.

Parece poco probable que, si la reina se hubiera querido hacer picar por un áspid, hubiera decidido bajarse el vestido para que le picara en el

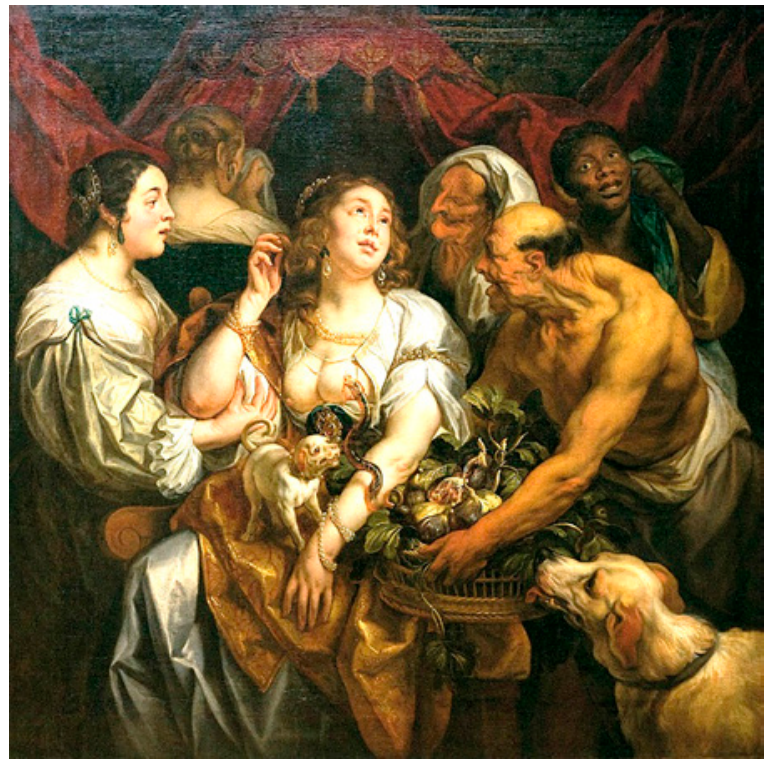

14. Jacob Jordanens, 1563, óleo sobre lienzo. Museumslandschaft Hessen Kassel pecho, o de manera más explícita en la areola, en vez de haber utilizado algo más fácil como el brazo o la pierna. A pesar de eso pintores como Guido Cagnacci la representaron así en sus diferentes variantes, su Cleopatra de 1660 (fig. 13) está sentada, con la corona puesta, desnuda de cintura para arriba y la serpiente subiendo por su lado derecho. En cambio, en su versión de 1662 mencionada en el apartado anterior (fig. 11), se baja explícitamente el vestido con la mano izquierda dejando el pecho al descubierto, para dirigir el áspid que se enrolla en su mano derecha para que le pique en él.

El caso de Guido Cagnacci es especialmente relevante, puesto que dedicó parte de su actividad a la pintura de salón privado, que incluía desnudos de cintura para arriba de personalidades como Cleopatra o Lucrecia. Tanto en un caso como en otro, se trata de desnudos innecesarios para la narración de la historia, que solo tienen cabida dentro del marco de la pintura erótica. Así, por ejemplo, en el caso de Lucrecia que fue violada, y se suicidó delante de su familia, no tiene ningún sentido que se la pinte desprovista de ropa. La matrona romana tuvo tiempo de sobra para vestirse, y resulta poco creíble que esta mujer, exemplum de buena esposa, recibiera a estos hombres con los pechos al aire (Valtierra, 2014-2015). De esta manera, se trata de una recreación plástica muy libre que solo tiene cabida dentro del marco de la pintura erótica. Además, el hecho de que los mismos pintores repitan temas con fórmulas iconográficas similares ahonda en la idea de que debió de ser un tema popular entre cierto grupo de coleccionistas. Sin embargo, hay una diferencia entre este tipo de mujeres con Cleopatra: Lucrecia prefirió la muerte al deshonor, y María Magdalena, figura también popular en estos repertorios, es una arrepentida. A pesar 

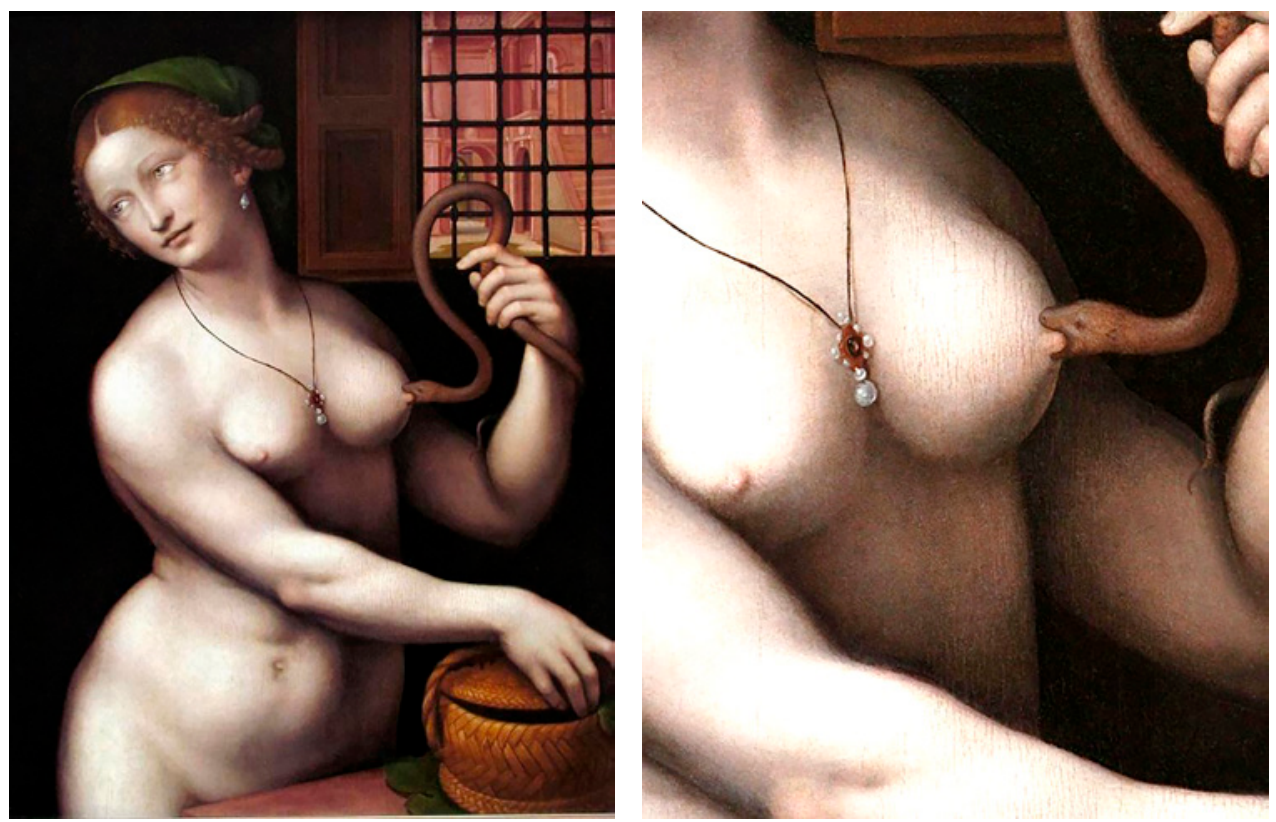

15. Giampietrino, ca 1500, óleo sobre lienzo. Museo del Louvre. Vista general (izquierda) y detalle (derecha)

de eso es constante la asociación explícita que se hace en la iconografía de Lucrecia y Cleopatra, y los mismos artistas a veces tratan ambos temas. Es el caso de Guido Reni, del que conservamos en el Museo del Prado una Lucrecia dándose muerte

Los ejemplos son numerosos, y a cada cual más variopinto. Jacob Jordaens en 1563 (Museumslandschaft Hessen Kassel) retrata a un nutrido grupo de personas (fig. 14). Un hombre ajado por la edad le acerca a la reina un cesto de higos, del cual sale una serpiente que le pica en el pecho izquierdo. De la herida, sale sangre. Cleopatra, con un perrillo en su regazo y otro más grande en el lateral, alza sus ojos al cielo mientras llora, como si fuera una santa en el proceso de su martirio encomendándose a dios. Sus esclavas también lloran desconsoladas. Tanto, que una de ellas gira su rostro porque no puede contemplar la tragedia.

La idea de que el áspid picó de manera explícita a Cleopatra en el pezón se materializó en el arte una manera terriblemente explícita, y con composiciones muy sugerentes. Es el caso de la obra de Giampietrino de ca 1500 del Museo del Louvre (fig. 15), donde Cleopatra desnuda y de frente, ha abierto el cesto de higos y la serpiente, a la que sostiene con su mano derecha, le pica en el pezón izquierdo. A pesar de eso, ella mantiene su gesto impertérrito. Un colgante cae entre sus dos pechos, acentuando el erotismo.

Otras veces, incluso de duplican las serpientes: una para cada pezón. Es el caso del óleo de un maestro flamenco anónimo del siglo XVII (Colección privada) donde la soberana va vestida a la moda barroca con sombrero de plumas y un vestido muy recargado que deja sus pechos al descubierto (fig. 16). Hay dos serpientes, otra 
vez más de tamaño muy reducido, que se dirigen cada una a un pezón para picarla. Es cierto que el hecho de que aparezcan dos serpientes puede deberse a una interpretación del plural poético bastante común en la literatura augustea (Sánchez y González, 2009, p. 238), pero también lo es que la iconografía interpretó este aspecto en su máximo exponente. Así, la pintura del maestro flamenco anónimo representa una Cleopatra ricamente ataviada, que solo deja al descubierto sus pechos, cuyos pezones son picados respectivamente por sendas culebrillas de tamaño minúsculo.

Es evidente que esta versión de la historia entra en contradicción directa con muchas de las fuentes antiguas como por ejemplo Plutarco (Antonio, $86,1-7)$ quien habla del brazo como lugar donde se produjo

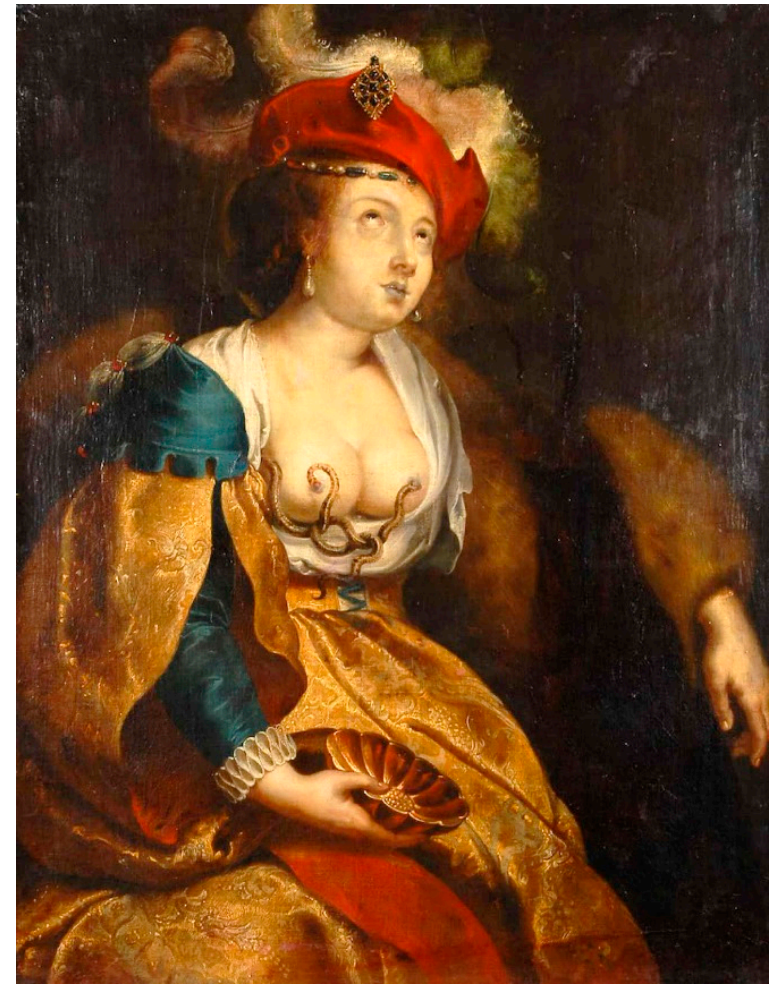

16. Maestro flamenco anónimo, siglo XVII, óleo sobre lienzo. Colección particular

la agresión. Sin embargo, el hecho de introducir esta variante iconográfica, basada quizá en ciertas fuentes antiguas del bando de Octavio que tan solo pretendían resaltar el aspecto erótico de la reina, no hace más que enfatizar la intención sexual de la pintura. Evoca en la mente del voyeur la idea de que él mismo podría ser ese reptil, convirtiendo los pechos de Cleopatra en el objeto de deseo de sus labios. Es una imagen que nada tiene que ver con la realidad del suicidio de la reina y que, reproducida hasta la saciedad, contribuyó a corromper la reputación de una de las mujeres con más poder y prestigio político de la época.

\section{5.- Conclusiones}

Es evidente que las representaciones pictóricas de Cleopatra están muy alejadas de la realidad histórica de lo que debió suceder. Ella era ante todo una reina, una poderosa gobernante capaz e inteligente que veló por el bienestar de su pueblo. También una madre orgullosa, que buscó la protección y un futuro mejor para sus hijos. A pesar deeso, y fruto de la campaña de desprestigio explícita y malintencionada del bando ganador romano de la guerra civil, hemos arrastrado hasta nuestros días la idea de la reina como femme fatale, como una especie de devora-hombres capaz 
de todo con tal de tener poder, y cuya biografía se narra en función de sus amantes. Una imagen fraudulenta de la reina que poco o nada tiene que ver con la realidad, y que se repite de manera reiterada en toda la pintura posterior.

A partir sobre todo del siglo XVI, comenzaron a proliferar una serie de imágenes fuertemente erotizadas cuyo destino final, en muchas ocasiones, era el disfrute del coleccionista que las poseyera. Cleopatras desnudas, que solo podemos reconocer por el áspid, o que se bajan el vestido para ser picadas en el pezón. También el tamaño del áspid quedó reducido casi al de una lombriz. El mito fue creciendo, y con él la idea de mujer sexual y seductora que fallece de la misma forma que teóricamente había vivido: haciendo gala de su libidinosidad. De esta manera su leyenda, ya de por sí falseada por la propaganda romana, se fue acrecentando con el paso de los siglos iconográficamente hablando. Ni siquiera la pintura del siglo XIX con un afán más reconstructivista, escapó de esta imagen. Así, encontramos ejemplos que siguen de manera casi literal la narración de Plutarco, donde se especifica que murió con la dignidad de una reina, pero en la que se la pinta desnuda sobre la cama.

Sabemos que Cleopatra murió como una reina, vestida como tal, muy lejos del icono que tanto Octavio como la pintura posterior han intentado transmitirnos. La propaganda política romana vilipendió su reputación para justificar su propia atrocidad de encontrase sumisos en una guerra civil. De esta manera se construyó una imagen totalmente distorsionada que se fue engrandeciendo con el paso de los siglos. La iconografía pictórica no solo recogió estas falsedades en torno a la figura de la reina, sino que creó un género propio en torno a su figura en el que su cuerpo desnudo, sus pezones y un áspid del tamaño de un gusano cobraron un protagonismo inusitado.

\section{Referencias-Bibliografía}

Alfonso García, Ma del Carmen (1999): «Mujer y fin de siglo (xIx): un uso intencionado de la mitología», en Corona Spicea. In Memoriam Cristóbal Rodríguez Alonso. Oviedo: Universidad de Oviedo, pp. 665-676.

Arroyo De La Fuente, Ma Amparo (2013). «Cleopatra viI Philopator y la legitimación del poder ptolomaico» en Eikon/Imago, No 4-2, pp. 69-106.

BornAY, Erika (1990). Las hijas de Lilith, Madrid: Cátedra.

Boyer, Phillippe (2004). «Cléopâtre vs. Lucrèce. Du suicide comme vecteur de rapprochement» en RitschaRd, Claude y MoreheAd, Alison, Cleopatre Dans Le Miroir de L' Art Occidental, Génova: 5 Continents Editions, pp. 53-59.

Browne, Thomas (1646-1672). Pseudodoxia Epidemica, or, Enquiries into Very many Received Tenets, and commonly Presumed Truths.

BuRKe, Jill (2016). «The European Nude 1400-1650» en Splendor, Myth, and Vision: Nudes from the Prado, Clark Art Institute/Museo Nacional del Prado, pp. 16-49. 
Calvat, Renaud (1995). «The Erotics of Absolutism: Rubens and the Mystification of Sexual Violence» en Broude, Norma y Garrard, Mary D., The Expanding Discourse: Feminisme and Art History, Nueva York: Icon, pp. 140-159.

CARrol, Margaret D. (1992). «The European Nude 1400-1650» en Splendor, Myth, and Vision: Nudes from the Prado, Clark Art Institute/Museo Nacional del Prado, pp. 16-49.

Castro Santamaría, Ana (2014). «Ilustres suicidas: Cleopatra y Lucrecia en palacios salmantinos del siglo XVI» en GARcía NistaL, Joaquín (coord.), Imagen y documento: materiales para construir una historia cultural, León: El Forastero, pp. 37-60.

CHAdwick, Whitney (1999). Mujer, arte y sociedad, Madrid: Destino.

Cid López, Rosa María (2000). «Cleopatra: mitos literarios e historiográficos en trono a una reina» en Studia historica. Historia antigua, No32, pp. 119-141.

Clayton, Peter A. (1985). Redescubrimiento del Antiguo Egipto. Artistas y viajeros del siglo XIX. Barcelona: Serbal.

Clark, Kenneth (2006). El desnudo, Madrid: Alianza.

DAUPHINÉ, James (1995). «La séduction de la blondeur ou le paradoxe de Cléopâtre» en REAL, Elena, El arte de la seducción en el mundo románico, medieval y renacentista, Valencia: Universitat de València, pp. 95-102.

De Callatä̈, François. Cléopâtre, usages et mésusages de son image, Bruselas: Académie royale de Belgique.

DE JEAN, Joan (2003). «Violent Women and Violence against Women: Representing the 'Strong' Woman in Early Modern France» en Signs No23, pp. 126-131.

De Meulenaere, Herman (1992). L'Égypte ancienne dans la peinture du xixe siècle, París: Berko.

DiJKstRA, Bram (1986). Ídolos de perversidad. La imagen de la mujer en la cultura de fin de siglo. Madrid/Barcelona: Debate.

Dottin-Orsini, Mireille (1992). Cette femme qu'ils disent fatale. Textes et images de la misogynie finde-siècle, París: Bernard Grasset.

EetesAm PÁrraga, Golrokh (2009), «Lilith en el arte decimonónico. Estudio del mito de la femme fatale» en Signa $\mathrm{N}^{\circ} 18$, pp. 229-249.

Fletcher, Joann (2009), Cleopatra the Great: The Woman Behind the Legend, Londres: Hodder.

Gámez SAlas, José Miguel (2019). «Artemisia Gentileschi: drama, venganza y feminismo en su obra» en Asparkía No34, pp. 109-133.

Garrard, Mary D. (1989). Artemisia Gentileschi: The Image of the Female Hero in Italian Baroque Art, Princeton: Princeton University Press.

HAMER, Mary (2001). «The Myth of Cleopatra since Renaissance» en WALKER, Susan y Higgs, Peter, Cleopatra of Egypt, fron HIstory to Myth, Princeton: Princeton University Press pp. 302-311.

Hamer, Mary (2009). Signs of Cleopatra: Reading an Icon Historically, Exeter: University of Exeter Press.

Hugues-Hallett, Lucy (1990). Cleopatra, Histories, Dreams and Distortions, Nueva York: Bloomsbury. 
Humbel, Jean Marcel (1989). L'Égyptomanie dans l'art occidental. París: ACR.

Jiménez-Belmonte J (2011). «Historiar el Oriente: Cleopatra en la historiografía española del siglo XVIII» en eHumanista $\mathrm{N}^{\circ} 17$, pp. 286-310.

LiNDSAY, Jack (1971). Cleopatra, Nueva York: Coward-McCann.

LunA, José J. (2016). «Guido Reni. Cleopatra» en Splendor, Myth, and Vision: Nudes from the Prado, Clark Art Institute/Museo Nacional del Prado, pp. 152-155.

Martin, Paul M. (1990). Antoine et Cléopâtre. La fin d'un rêve, París: Albin Michel.

Miles, Margaret Melanie (2011). Cleopatra: a Sphinx Revisited, California: University of California Press.

Nead, Lynda (1998). El desnudo femenino. Arte, obscenidad y sexualidad, Madrid: Tecnos.

Parramore, Lynn (2008). Reading the Sphinx. Ancient Egypt in Nineteenth-Century Literary Culture, Basingstoke: Palgrave Macmillan.

Pelline, Christopher (2001). "Anything truth can do, we can do better: the Cleopatre legend» en Walker, Susan y Higgs, Peter, Cleopatra of Egypt, fron History to Myth, Princeton: Princeton University Press pp. 292-301.

PRAz, Mario (1969). La carne, la muerte y el diablo en la literatura romántica, Caracas: Rubén Mettini.

PRAz, Mario, (2007). El paralelismo entre la literatura y las artes visuales, Madrid: Taurus.

Poblador Muga, María Pilar (2017). «Cleopatra, entre el amor y la muerte, una musa para la pintura del siglo XIX» en CAstan, Alberto y LombA, Concha, Eros y Thánatos: reflexiones sobre el gusto III: Simposio, Zaragoza, Paraninfo de la Universidad de Zaragoza, 16, 17 y 18 de abril de 2015, Zaragoza: Institución Fernando el Católico, pp. 207-232.

Pomeroy, Sarah B. (1984). Women in Hellenistic Egypt from Alexander to Cleopatra, Nueva York: Schoken.

Porzio, Giuseppe (2014). "A new Cleopatra» en Porzio, Giuseppe y Terzagh, María Cristina, Artemisia Gentileschi. Cleopatra, París: Gallerie G. Sarti, 8-30.

Primo CANo, Carlos (2017). Arquetipos de la crueldad femenina en la literatura y la pintura de entresiglos (1870-1930). Madrid: Universidad Complutense de Madrid (tesis doctoral).

PuyAdAs Rupérez, Vanessa (2016). Cleopatra VII: la creación de una imagen. Representación pública y legitimación politica en la Antigüedad. Zaragoza: Prensas de la Universidad de Zaragoza.

Quesada Monge, Rodrigo (2000). «Mujeres eternas. Enheduanna - Hatshepsut Nefertiti - Cleopatra» en Perspectivas, No2, pp. 99-111.

Retief, François Peter y Cilliers, Louise (2005). «The death of Cleopatra» en Acta Theologica, Supplementum 7, pp. 79-88.

RichARD-JAMET, Céline. «Cléopâtre: femme forte ou femme fatale? Une place équivoque dans les Galeries de femmes fortes aux xvie et xvire siècles» en Ritschard, Claude y Morehead, Alison, Cléopâtre dans le miroir de l'art occidental, Génova: 5 Continents Editions, 37-52.

Roller, Duane W. (2010). Cleopatra: a biography, Oxford: Oxford University Press. 
Romero De Solís, Diego (1997). «El miedo a la mujer (arte, sexualidad y fin de siglo)», en Daimon. Revista de Filosofía N ${ }^{\circ} 14$. Murcia: Universidad de Murcia, pp. 155-166.

RUIz GARRIDo, Belén (2004). «Una nueva Cleopatra. Interrelaciones iconográficas en las imágenes femeninas de seducción de fin de siglo» en COLOMA MARTÍN, Isidoro et alii. (eds) Actas del XIV Congreso CEHA 2002: Correspondencia e integración de las artes, Málaga: Universidad de Málaga, pp. 521-543.

Ruiz GARrido, Belén (2006). "Yo soy Egipto. El poder y la seducción de Cleopatra en las artes plásticas y en el cine» en Baética. Estudios de Arte, Geografía e Historia No28, pp. 167-194.

Syme, Ronald (1989). La Revolución romana, Madrid: Taurus.

THORNTON, Lyanne (1985). La femme dans la peinture orientaliste, París: Art Creation Realisation.

Trape, Jean-François; ChIrio, Laurent; Broadley, Donald G. y Wüster, Wolfgang (2009). «Phylogeography and systematic revision of the Egyptian cobra (Serpentes: Elapidae: Naja haje) species complex, with the description of a new species from West Africa» en Zootaxa $\mathrm{N}^{\circ}$ 2236-1, pp. 1-25.

VAltierRa LAcAlle, Ana (2014-2015). «Iconografía de Lucrecia. Repercusiones plásticas en la Península Ibérica» en Anas ((Museo Nacional de Arte Romano de Mérida) No27-28, pp. 241-261.

VALVERde, Isabel y PiCAzo, Marina (2008). « ¿La reina vencida? Cleopatra y el poder en el arte y la literatura» en CAstillo, María José (ed.), Congreso Internacional «Imagines», La Antigüedad en las Artes escénicas y visuales, Logroño: Universidad de La Rioja, pp. 525-528.

Vanlathen, Marie-Paule (2005). «Cléopâtre dans le miroir de la peinture du XIX siècle» en Trabajos de Egiptología=Papers on Ancient Egypt No 4, pp. 129-146.

WALKer, Susan y Higgs, Peter (2001). Cleopatra of Egypt: from history to myth. Catálogo de la exposición, Londres: The British Museum Press.

WyKe, Maria (1992). «Augustan Cleopatras: Female Power and Poetic Authority» en Powell, Anton (ed.), Roman Poetry and propaganda in the Age of Augustus, Bristol: Bristol Classical Press, pp. 98-140.

Recibido el 25 de enero de 2020

Aceptado el 27 de abril de 2020 BIBLID [1132-8231 (2020): 27-49] 